International Journal of Engineering \& Technology, $7(3.29)(2018) 115-120$
SPC
International Journal of Engineering \& Technology
Website: www.sciencepubco.com/index.php/IJET
Research paper

\title{
Land use change impact on flood reduction capacity of lake sentani, jayapura
}

\author{
Elroy Koyari ${ }^{1}{ }^{*}$, Runi Asmaranto ${ }^{2}$ \\ ${ }^{1}$ Water Resources Engineering, Faculty of Engineering, Brawijaya University, Malang, Indonesia \\ ${ }^{2}$ West Papua River Basin Agency, Manokwari, Indonesia \\ *Corresponding author E-mail: elroykoyari@yahoo.co.id
}

\begin{abstract}
Flood is a natural phenomenon that occurs in certain places due to natural causes and human activities. However, the imbalance in hydrological cycle will cause the flood to do damage, both materially and non-materially. Therefore, it is important to control the occurrence and magnitude. Human activities that can cause such imbalance, one of them, is land use change. Many areas of pervious area are shifting into impervious areas, which will increase the amount of surface runoff generated. This research will cover about how land use changes over the year can influence the surface runoff generated in a certain area. This research is conducted in Sentani watershed, Jayapura, Papua, Indonesia. Calculation with the aid of ArcMap 10.1 and WinTR-20 results in around 6\% changes in flood discharge in the outlet for land use in year 2007, 2010, 2012, and 2016. The reservoir capacity in reducing flood discharge is also increasing over the years.
\end{abstract}

Keywords: Flood; Lake Sentani; Land Use Change; SCS-CN Model.

\section{Introduction}

Flood is a natural phenomenon that occurs in certain places. It is caused both by natural forces and human activities. By natural forces, flood can occur due to heavy rain in such short amount of time. Aside from natural causes, flood can also be caused by the expansion of human activities. One of the example is the change of land use due to the increment of human activities. Such cause may directly cause shifting in land cover from pervious cover to impervious cover in order to fulfill the rapidly growing demands of human activities. This phenomenon can happen everywhere, not only in urban areas but also suburban and rural areas can suffer from it too. flood occurs when a river bursts its banks and the water spills onto the floodplain. Flooding tends to be caused by heavy rain: the faster the rainwater reaches the river channel, the more likely it is to flood. The nature of the landscape around a river will influence how quickly rainwater reaches the channel [1] (River Flooding and Management Issues, n.d.).

Flood certainly brings damage both material-wise and non-material-wise. In material aspects, there are damages which sum up to hundreds of billion rupiah, depending on the location and density of the area. The denser and more important the flood location, the damage will also be more latent. As for the nonmaterial-wise, one of the example is casualties in the form of human lives caused by flood. This depends also on location and density in the area. One of the causes in imbalance in hydrologic cycle is changes in land use Over the year, along with the rapid development of human activities, they will demand more area to hold activities, hence changes in land use. The main point of this change is how previously pervious area are shifting into impervious area, which obviously will affect how the area reacts to the same rainfall event.

Sentani watershed has gone through land use change as the years go by. According from the land use distribution data in Sentani watershed throughout the years, there is an increment of 5.35\% from
2007 to 2010 , and $5.08 \%$ from 2010 to 2012 . This is mainly caused by the development of human activities that are centered in the surrounding area. Lately, Sentani Lake also suffers from shallowing due to land erosion, considering that the slope between Cyclops Ridge and Sentani Lake is quite steep. Aside from that, the activities in the catchment area which triggers land use change also increase critical land potential within the watershed.Along with land use change phenomenon, it is certain that there will also be changes in terms of rainfall runoff pattern occurred in the watershed. The problem with pervious cover area turning into impervious cover area possess great threat, that is the increment of surface runoff volume. This research will find out about the impact of land use change to surface runoff pattern in Sentani watershed, which has 14 subwatersheds. This paper will also discuss about the effectivity of Sentani Lake in flood reduction.

\section{Study area description}

This research revolves around Sentani Lake, Jayapura. This lake has the watershed, Sentani watershed, which consists of 14 sub-watersheds around it. All of these sub-watersheds are emptying into Sentani Lake. Sentani Lake's location is surrounded by Cyclops Ridge with extremely steep slope, hence it is to be expected that the lake suffers a lot from sedimentation which makes the lake's depth decrease.

Lake Sentani is one of the lakes located in Jayapura District, Papua. This lake is located between Jayapura City and Jayapura District, with the coordinates of $140 \mathrm{o} 23^{\prime}-140$ o 50 ' BT dan 2o 31'-2o 41' LS. Geographically, Sentani Lake is surrounded with East Sentani district, Sentani district, West Sentani district, Kemtuk district, Kemtuk Gresi district, Abepura district, and Jayapura city. 


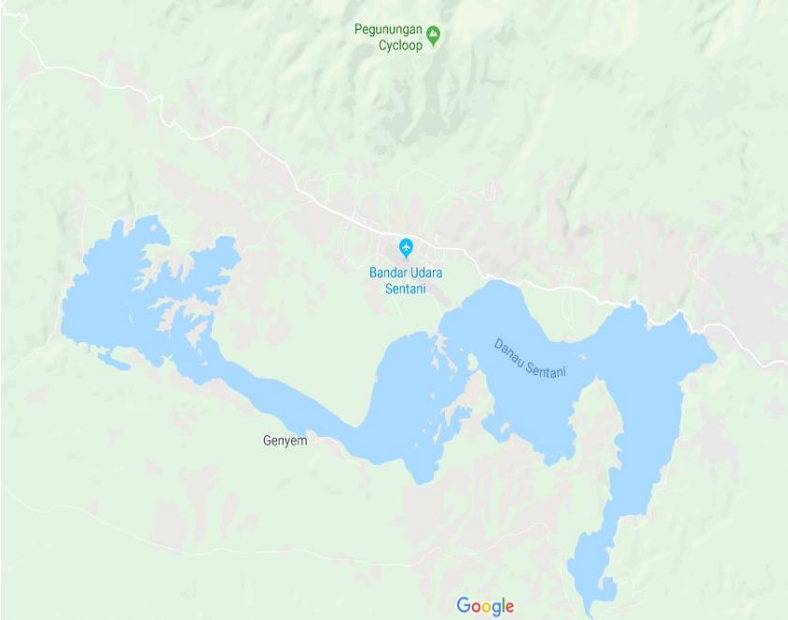

Fig. 1: Sentani Lake.

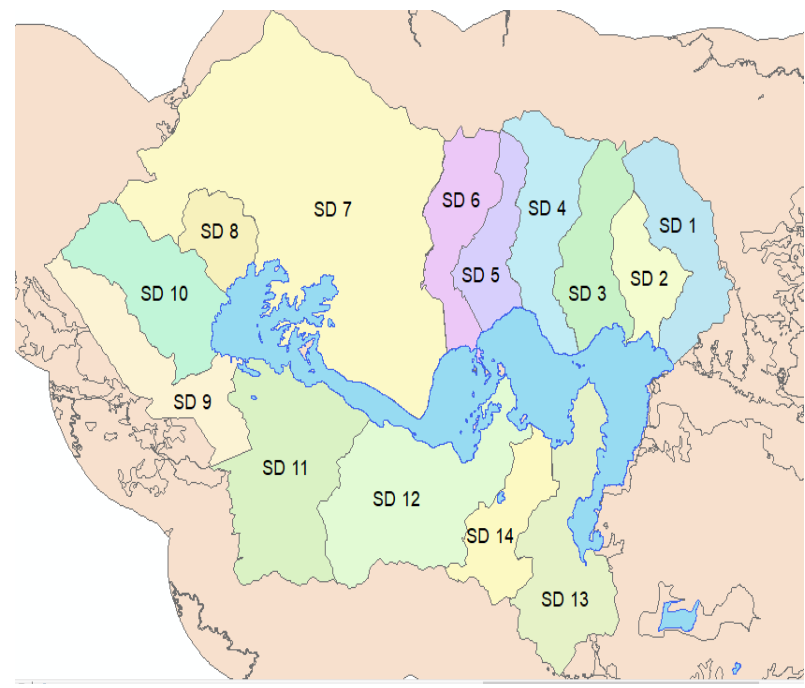

Fig. 2: Sub-Watershed of Sentani Watershed.

Last year in 2013, Lake Sentani water level increase of $1-2 \mathrm{~m}$ caused the inundation area around Lake Sentani. The puddle has resulted in billions of rupiah losses as reported by the tempo Wednesday, March 27, 2013. The phenomenon of rising water levels according to Tempo, quoting from Papua Governor Constant Karma, is one of the reasons that exist around Lake Sentani. lake as high as less as $2 \mathrm{~m}$ Said phenomenon is known as groundwater flood (Levi, 2013). [2]

Another analysis states that in Sentani watershed especially on Lake Sentani, water level increase is caused by high rainfall, the rate of erosion and slope of the Sentani basin is greater than $5 \%$. These conditions lead to erosion and sedimentation that impact on the rise of waterfront Sentani lake [3]. Another analysis suggests that increasing critical land and high rainfall intensity in the upper reaches of Lake Sentani can lead to an increase in lake water levels, as upstream rainfall runoff will enter as an inflow on Lake Sentani [4].

\section{Basic concepts}

The amount of water in Earth will relatively be the same from time to time. This is because the amount of water is going through a natural cycle called hydrologic cycle [5]. To put it simply, the heat transfer from sun and other climate factors will cause water to evaporate into the atmosphere. Evaporation occurs not only in water body, but also from plants' transpiration. This evaporation will result in condensation in the atmosphere when the temperature is cold enough. The result of this condensation is precipitation in other parts of the earth, if the resulting condensation is brought to other parts of the earth by wind. The result of precipitation will also go through several alternatives of process. Some will be retained by vegetation and absorbed, some will infiltrate into soil layer and the rest will produce surface runoff. The infiltrated water will also have two options, either the water will be percolated into deeper layer of rock soil or forming groundwater layer.

All the water going through hydrologic process will eventually be flowing back into water bodies, in which the cycle will start all over again. This process happens continuously. Although the cycle is balanced by default, disturbances from external factors will overthrow the balance. One of the resulting phenomenon from hydrologic cycle imbalance is flood.

One of the methods used to calculate flood discharge is SCS-CN method. Although there are many other methods to calculate flood discharge, it depends on the study area and circumstances. In this research, SCS-CN method is used. This method was developed by USDA Soil Conservation Service, which is basically a hydrological model to estimate the amount of flood by adopting watershed characteristics. This method estimates the volume of flood based on land cover type, humidity of the soil based on preceeding rainfall of five days in the area, and soil type [6]. The equation for SCS-CN model according to rainfall height calculation [7] is as follows:

$$
\begin{aligned}
& Q=\frac{\left(P-I_{a}\right)^{2}}{\left(\left(P-I_{a}\right)+S\right)} \text { for } P>0.2 S \\
& Q=0 \text { for } P>0.2 S
\end{aligned}
$$

Where:

Q: Discharge (cms)

P: Rainfall accumulation ( $\mathrm{mm}$ )

$\mathrm{S}$ : Maximum reservoir capacity after runoff occurrence $(\mathrm{mm})$

IA: Initial abstraction ( $\mathrm{mm})$, can be predicted with empirical formula (I_a=0.2 S)

WinTR-20 is a hydrological modelling tools developed by United States Department of Agriculture. WinTR-20 uses SCS-CN method-based calculation. This model is a storm event surface water hydrologic model applied at a watershed scale. This model assists in the hydrologic evaluation of flood events for use in the analysis of water resource projects (USDA, 2015) [8]. Based on this, this program can also model several changes or design alternatives and the impact within the watershed.

\section{Methodology}

In order to acquire each sub-watershed properties, such as land cover, slope, and area, a geographical-based software is needed. In this case, ArcMap v10.1. This program which was developed by ESRI is used to determine the geographical properties of the watershed.

After the collection stage of geographical properties of the watershed, a further analysis is needed. For the rainfall input, data from rain gage stations are gathered. There are three rain gage stations which has influence on the watershed: Genyem, Sentani, and Jayapura. All three of them each has different (USDA, 2015)percentage of impact on Sentani watershed.

Combining both geographical information of the watershed and rainfall data requires yet another software. WinTR-20 is a rainfallrunoff simulation model. It is meant to perform a hydrological model in a watershed with the area of minimum 0.1 acre or minimum time of concentration (Tc) of 0.6 minute [8]. WinTR-20 adapts the calculation method of SCS-CN (Soil Conservation Service - Curve Number).

The complete steps for this research is explained in the following flowchart. 


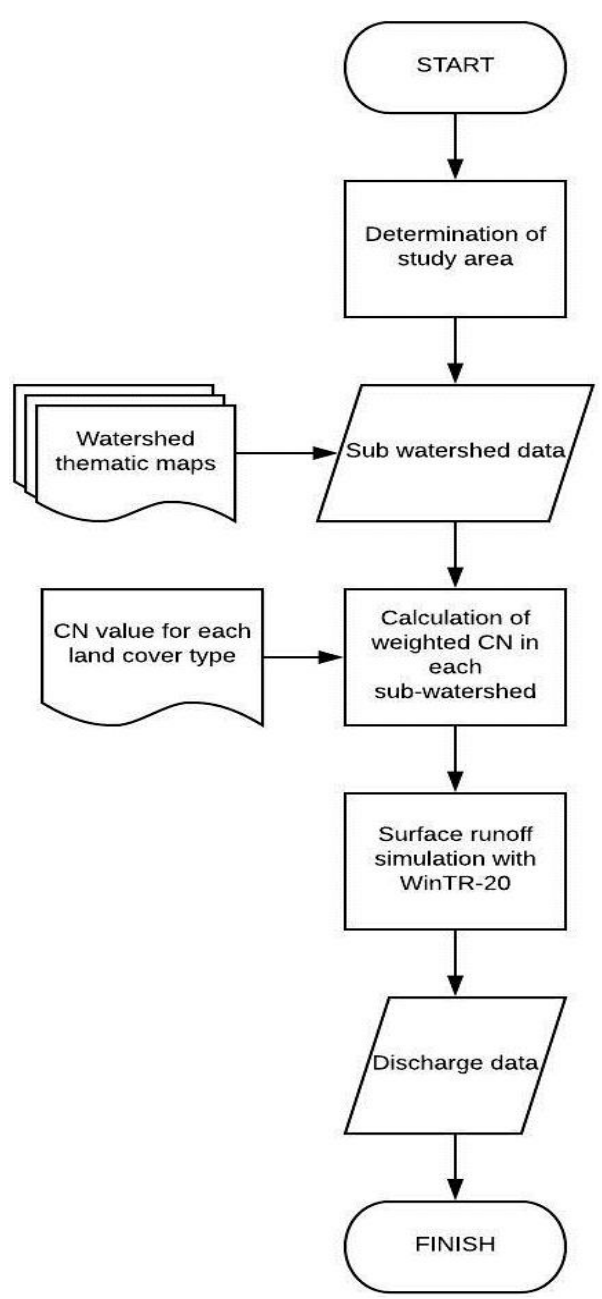

Fig. 3: Research Flowchart.

\section{Results and discussions}

The first step of this research is to determine how changes in land cover composition over the year can affect the amount of runoff produced by a certain rain event. The rain event will be determined as hypothetical data taken from one of the data in the rain gage stations that affects Sentani watershed. The rain is considered as uniformly distributed throughout the whole area. Although this may not happen frequently. After determining the rain that will be simulated, the next step is to run the simulations with different landcover for each time. As for the available data, the land cover data for Sentani watershed is obtained from Balai Wilayah Sungai Papua. There are three years variation of land cover map, which are from year 2007, 2010, and 2012. As for the newest land cover map, the year 2016, it is obtained from Geography Department, Faculty of Mathematics and Natural Science, Universitas Indonesia.

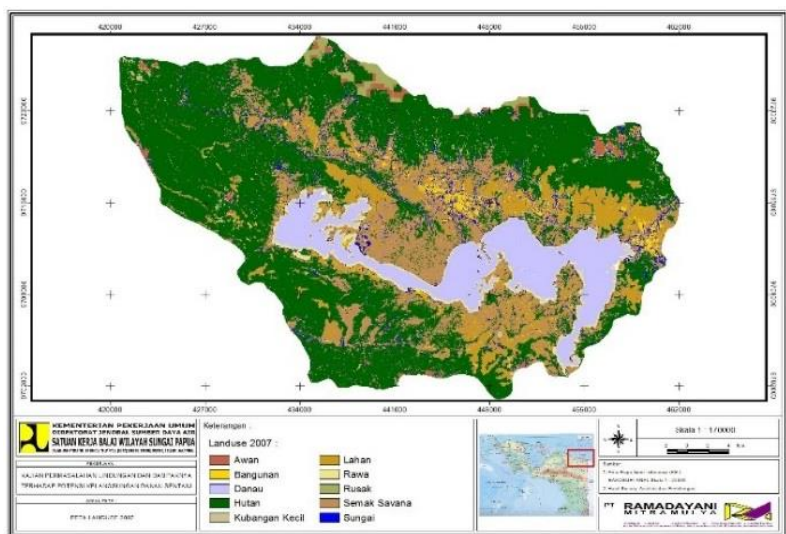

Fig. 4: Sentani Watershed Land Cover in 2007.

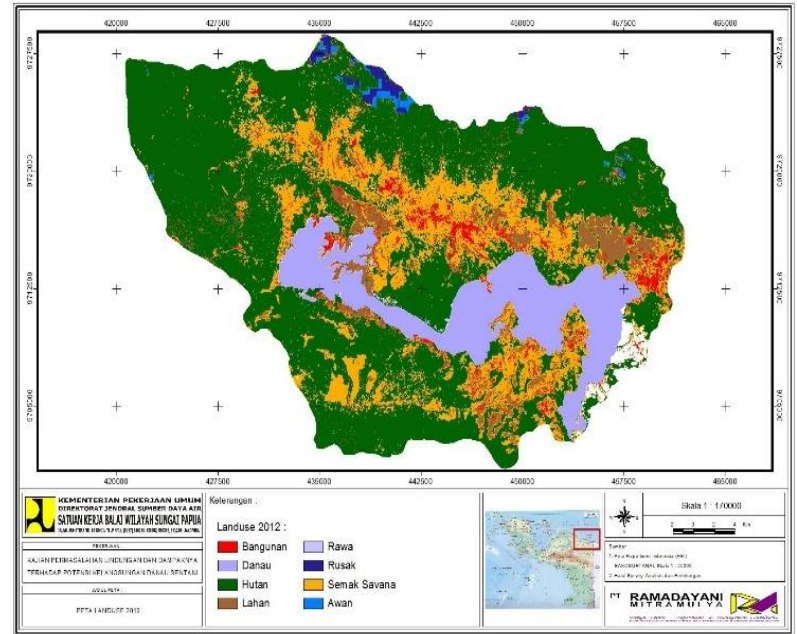

Fig. 5: Sentani Watershed Land Cover in 2010.

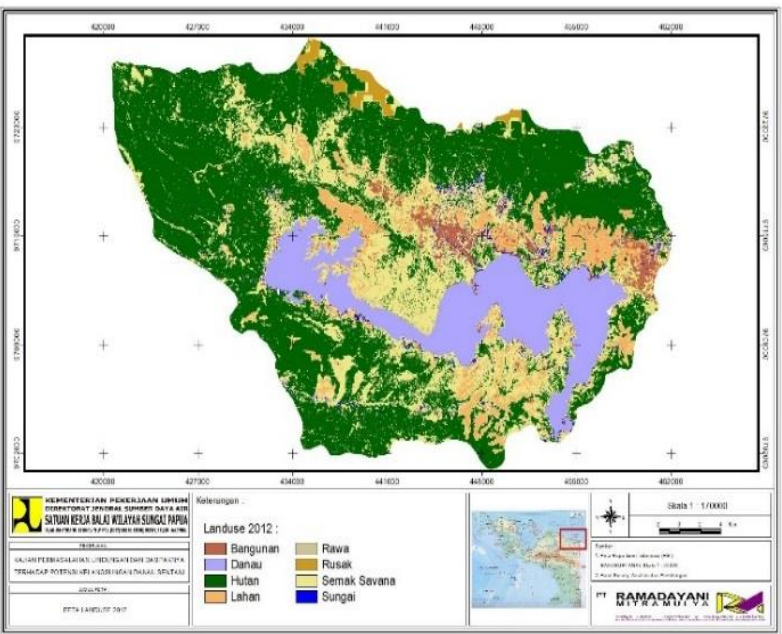

Fig. 6: Sentani Watershed Land Cover in 2012.

It can be seen from above that there are several changes in terms of land cover in Sentani watershed. There is a bit of noticeable growth in terms of impervious cover area, which increases about $5.3 \%$ from 2007 to 2010 , and $5.1 \%$ from 2010 to 2012 . As the consequences, the forest area is decreasing for about $4.75 \%$ from 2007 to 2010, then decreasing yet again to almost $5 \%$ in the span of just two years. In order to determine the amount of surface runoff produced by each sub-watershed, it is of the essential to determine the properties of each sub-watershed first. The table below explains the properties of each sub-watershed, which is assumed to not change throughout the years.

Table 1: Sub-Watershed Properties of Sentani Watershed

\begin{tabular}{|c|c|c|c|c|}
\hline $\begin{array}{l}\text { Sub-water- } \\
\text { shed }\end{array}$ & $\begin{array}{l}\text { Area }(\mathrm{sq} \\
\mathrm{km})\end{array}$ & $\begin{array}{l}\text { Length of main river } \\
\text { (m) }\end{array}$ & $\begin{array}{l}\text { Slop } \\
\text { e }\end{array}$ & $\begin{array}{l}\text { Tc } \\
\text { (hour) }\end{array}$ \\
\hline Expo & 34500 & 14877.028 & $\begin{array}{l}0.06 \\
6\end{array}$ & 1.507 \\
\hline Tlaga Ria & 24380 & 7769 & $\begin{array}{l}0.06 \\
7\end{array}$ & 0.912 \\
\hline Harapan & 18887 & 9070.911 & $\begin{array}{l}0.10 \\
7\end{array}$ & 0.856 \\
\hline Yakembeng & 32553 & 13061 & $\begin{array}{l}0.07 \\
2\end{array}$ & 1.325 \\
\hline Netar & 24809 & 12243 & $\begin{array}{l}0.10 \\
3\end{array}$ & 1.094 \\
\hline Kuruwaka & 23480 & 12165 & $\begin{array}{l}0.12 \\
8\end{array}$ & 1.004 \\
\hline Yahim & 236089 & 33670 & $\begin{array}{l}0.04 \\
2\end{array}$ & 3.360 \\
\hline DAS 1 & 17161 & 5010.262 & $\begin{array}{l}0.05 \\
8\end{array}$ & 0.686 \\
\hline DAS 3 & 29682 & 6822.837 & $\begin{array}{l}0.04 \\
8\end{array}$ & 0.941 \\
\hline
\end{tabular}




\begin{tabular}{|c|c|c|c|c|}
\hline DAS 2 & 25545 & 6281.181 & $\begin{array}{l}0.07 \\
2\end{array}$ & 0.753 \\
\hline DAS 4 & 64168 & 14099.335 & $\begin{array}{l}0.05 \\
3\end{array}$ & 1.577 \\
\hline Hendo & 40271 & 5815 & $\begin{array}{l}0.02 \\
5\end{array}$ & 1.060 \\
\hline Belo & 23777 & 6733.888 & $\begin{array}{l}0.01 \\
5\end{array}$ & 1.459 \\
\hline Waisyake & 24892 & 10598 & $\begin{array}{l}0.01 \\
4\end{array}$ & 2.120 \\
\hline
\end{tabular}

These parameters are assumed to not change throughout the year, therefore they do not change in the WinTR-20 input. The only parameter that changes in the WinTR-20 input is the $\mathrm{CN}$ value for each year of simulation.

The changes of $\mathrm{CN}$ value in each sub-watershed is determined by two ways. As for 2007, 2010, and 2012 data, the table has already been done by Balai Wilayah Sungai Papua. Although the composition for each type of land cover has been determined, a further calculation is still needed nevertheless. By multiplying the percentage of each land cover type with corresponding $\mathrm{CN}$ value, the weighted $\mathrm{CN}$ value for each watershed is determined.

All that is left is to determine the land cover composition in 2016 data. This step needs aid from ArcMap 10.1, as the land cover map available for the year is in the format of .shp. After determining each land cover composition for each watershed, the calculation is the same with above. Multiplying each percentage of land cover with its corresponding $\mathrm{CN}$ value will produce the weighted value of $\mathrm{CN}$ for each watershed.

The result for all calculations regarding $\mathrm{CN}$ value is presented in the table below.

Table 2: Changes in CN Value for Each Sub-Watershed

\begin{tabular}{lllll}
\hline Sub-watershed & CN 2007 & CN 2010 & CN 2012 & CN - 2016 \\
\hline Expo & 54.951 & 57.639 & 60.327 & 52.646 \\
Tlaga Ria & 51.494 & 53.244 & 54.995 & 55.603 \\
Harapan & 52.497 & 51.969 & 51.441 & 54.924 \\
Yakembeng & 51.498 & 51.429 & 51.360 & 52.762 \\
Netar & 56.071 & 57.004 & 57.936 & 61.02 \\
Kuruwaka & 58.218 & 58.833 & 59.447 & 58.339 \\
Yahim & 53.095 & 53.500 & 53.904 & 55.301 \\
DAS 1 & 51.900 & 52.065 & 52.229 & 52.415 \\
DAS 3 & 48.557 & 48.371 & 48.184 & 45.867 \\
DAS 2 & 48.194 & 49.058 & 49.921 & 46.73 \\
DAS 4 & 51.001 & 51.308 & 51.614 & 49.229 \\
Hendo & 52.429 & 52.799 & 53.170 & 54.286 \\
Belo & 59.682 & 60.549 & 61.417 & 54.975 \\
Waisyake & 56.955 & 57.384 & 57.813 & 57.75 \\
\hline
\end{tabular}

The next step is to simulate the rainfall-runoff simulator using WinTR-20. This program is based on SCS-CN calculation method. It is necessary to determine first the parameters needed to simulate the whole system.

As much as the properties of each sub-watershed is of the essence, physical representative of the system is also as important. This can be described by schematic system of Sentani watershed. To put it simply, the whole schematic is that all sub-watersheds around the lake will meet their outlet in the lake, and then the lake will also have an outlet. Said schematic can be described with the figure below.

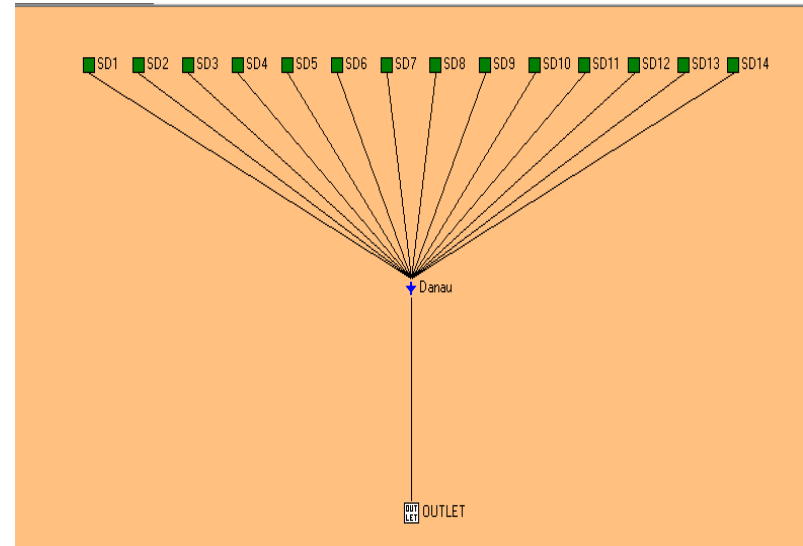

Fig. 7: Schematic System of Sentani Watershed.

The function of schematic is to determine where the outflow will come and go into and out of the system. Each of the system will be described with smaller system, called sub-watershed. The sub-watershed has their own properties, such as area, slope, $\mathrm{CN}$, and time of concentration. Time of concentration is the time needed for a drop of water to reach the outlet of the sub-watershed all the way from the upstream.

After determining the schematic and giving out properties in each sub-watershed, all that is left to do is to run the system. The program WinTR-20 will produce peak time and peak flow for each sub-watersheds in each scenarios, along with the discharge-time plot.

Table 3: Peak Time and Peak Flow Simulation Results for Each Sub-Watershed in Each Scenarios

\begin{tabular}{|c|c|c|c|c|c|c|c|c|}
\hline \multirow[t]{2}{*}{$\begin{array}{l}\text { Sub-wa- } \\
\text { tershed }\end{array}$} & \multicolumn{2}{|c|}{ CN 2007} & \multicolumn{2}{|c|}{ CN 2010} & \multicolumn{2}{|c|}{ CN 2012} & \multicolumn{2}{|c|}{ CN 2016} \\
\hline & Pea & Pea & Pea & Pea & Pea & Pea & Pea & Pea \\
\hline & $\mathrm{k}$ & $\mathrm{k}$ & $\mathrm{k}$ & $\mathrm{k}$ & k & $\mathrm{k}$ & $\mathrm{k}$ & $\mathrm{k}$ \\
\hline & Tim & Flo & Tim & Flo & Tim & Flo & Tim & Flo \\
\hline & e & w & $\mathrm{e}$ & w & e & w & e & w \\
\hline & (ho & (c & (ho & $(\mathrm{cm}$ & (ho & $(\mathrm{cm}$ & (ho & $(\mathrm{cm}$ \\
\hline & ur) & $\mathrm{ms})$ & ur) & s) & ur) & s) & ur) & s) \\
\hline \multirow{2}{*}{ Expo } & 13. & 7.1 & 13. & 12.1 & 13. & 18.6 & 13. & 414 \\
\hline & 32 & 1 & 18 & 5 & 15 & 4 & 76 & 4.14 \\
\hline \multirow{2}{*}{ Tlaga Ria } & 13. & 2.3 & 12. & \multirow{2}{*}{3.89} & 12. & \multirow{2}{*}{6.24} & 12. & \multirow{2}{*}{7.25} \\
\hline & 47 & 9 & 97 & & 81 & & 75 & \\
\hline \multirow{2}{*}{ Harapan } & 13. & 2.4 & 13. & \multirow{2}{*}{2.13} & 13. & \multirow{2}{*}{1.84} & 12. & \multirow{2}{*}{4.87} \\
\hline & 08 & 8 & 21 & & 44 & & 76 & \\
\hline Yakembe & 13. & 3.0 & 13. & 2.96 & 13. & 2.9 & $\begin{array}{l}13 . \\
53\end{array}$ & 4.15 \\
\hline \multirow{2}{*}{ Netar } & 12. & 7.5 & 12. & \multirow{2}{*}{9.15} & 12. & 10.9 & 12. & 18.2 \\
\hline & 91 & 5 & 9 & & 81 & 5 & 77 & 1 \\
\hline $\mathrm{Ku}-$ & 12. & 11. & 12. & 12.8 & 12. & 14.2 & 12. & 11.7 \\
\hline ruwaka & 73 & 46 & 72 & 1 & 71 & 3 & 73 & 2 \\
\hline \multirow{2}{*}{ Yahim } & 12. & 39. & 12. & \multirow{2}{*}{44} & 12. & 49.5 & 12. & 73.8 \\
\hline & 76 & 02 & 7 & & 65 & 6 & 58 & 1 \\
\hline \multirow{2}{*}{ DAS 1} & 13. & 1.9 & 12. & \multirow{2}{*}{2.07} & 12. & \multirow{2}{*}{2.17} & 12. & \multirow{2}{*}{2.3} \\
\hline & 01 & 6 & 96 & & 91 & & 86 & \\
\hline DAS 3 & $\begin{array}{l}15 . \\
57\end{array}$ & $\begin{array}{l}1.2 \\
9\end{array}$ & $\begin{array}{l}15 . \\
67\end{array}$ & 1.22 & $\begin{array}{l}15 . \\
73\end{array}$ & 1.17 & $\begin{array}{l}18 . \\
86\end{array}$ & 0.63 \\
\hline \multirow{2}{*}{ DAS 2} & 15. & 1.0 & 15. & 125 & 13. & 163 & 18. & 068 \\
\hline & 59 & 1 & 25 & 1.25 & 86 & & 14 & 0.00 \\
\hline & 13. & 7.2 & 14. & & 14. & & 15. & \\
\hline DAS 4 & 94 & 2 & 27 & 5.46 & 16 & 5.91 & 8 & 3.22 \\
\hline & 13. & 4.9 & 13. & 5.47 & 13. & 603 & 12. & 813 \\
\hline Hendo & 36 & 6 & 21 & 5.47 & 14 & 0.03 & 98 & 8.13 \\
\hline Belo & 13. & 11. & 13. & 13.5 & 13. & 15.3 & 13. & 5 \\
\hline Belo & 11 & 91 & 1 & 4 & 09 & 2 & 27 & \\
\hline Waisyake & $\begin{array}{l}13 . \\
74\end{array}$ & 6.5 & $\begin{array}{l}13 . \\
73\end{array}$ & 7 & $\begin{array}{l}13 . \\
72\end{array}$ & 7.53 & $\begin{array}{l}13 . \\
72\end{array}$ & 7.45 \\
\hline & 13. & 96. & 13. & 109. & 12. & 128. & 12. & 131. \\
\hline Danau & 1 & 14 & 01 & 61 & 91 & 87 & 71 & 17 \\
\hline Outlet & 20. & 35. & 20. & 37.7 & 20. & 41 & 20. & 39.7 \\
\hline Outiet & 56 & 37 & 33 & 1 & 06 & 41 & 08 & 3 \\
\hline
\end{tabular}


(A)

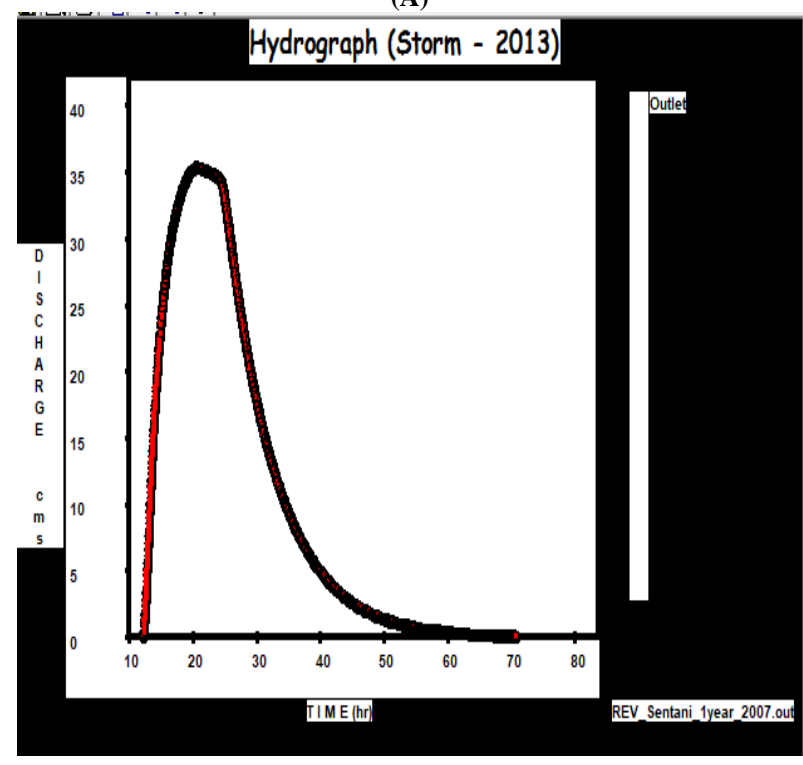

(B)

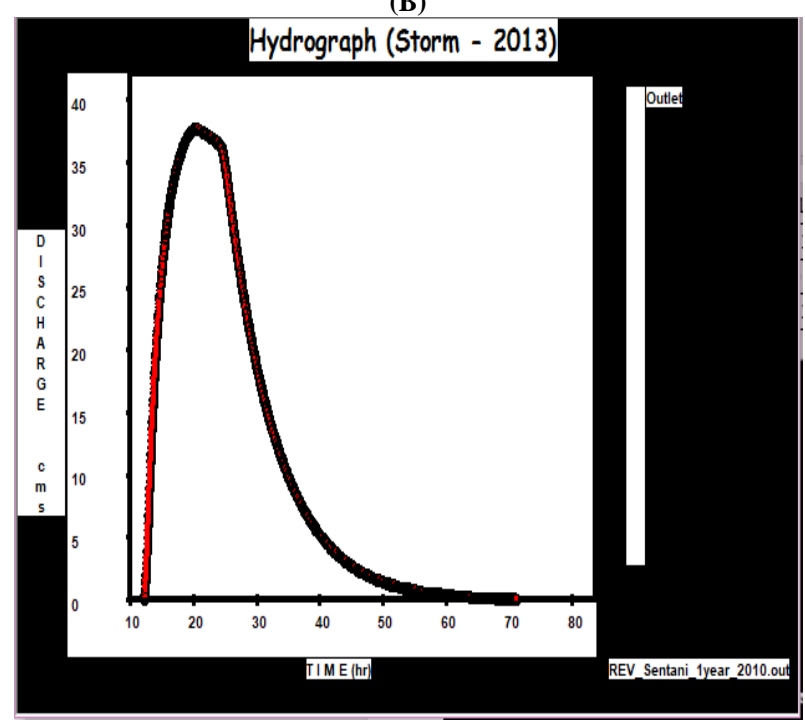

(C)

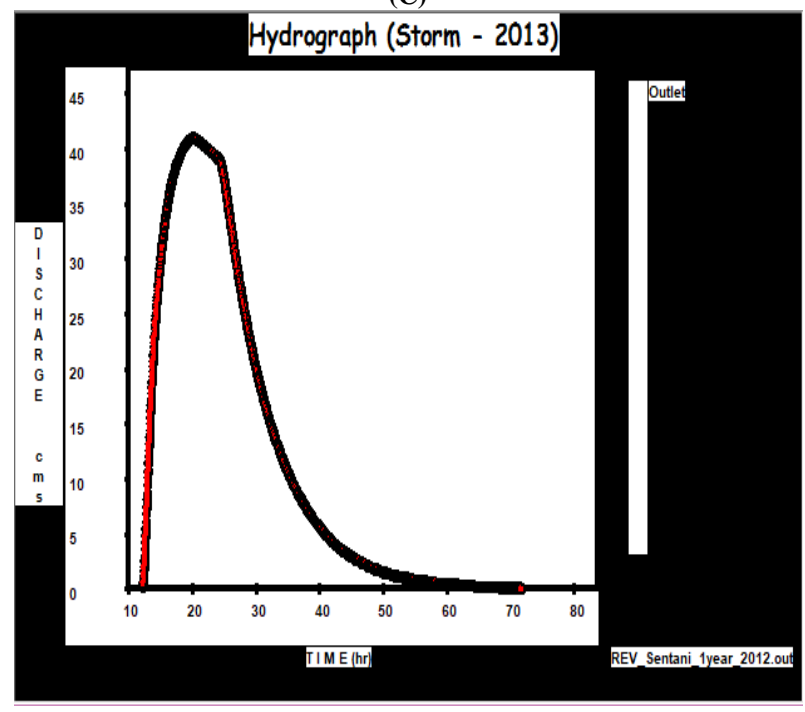

(D)

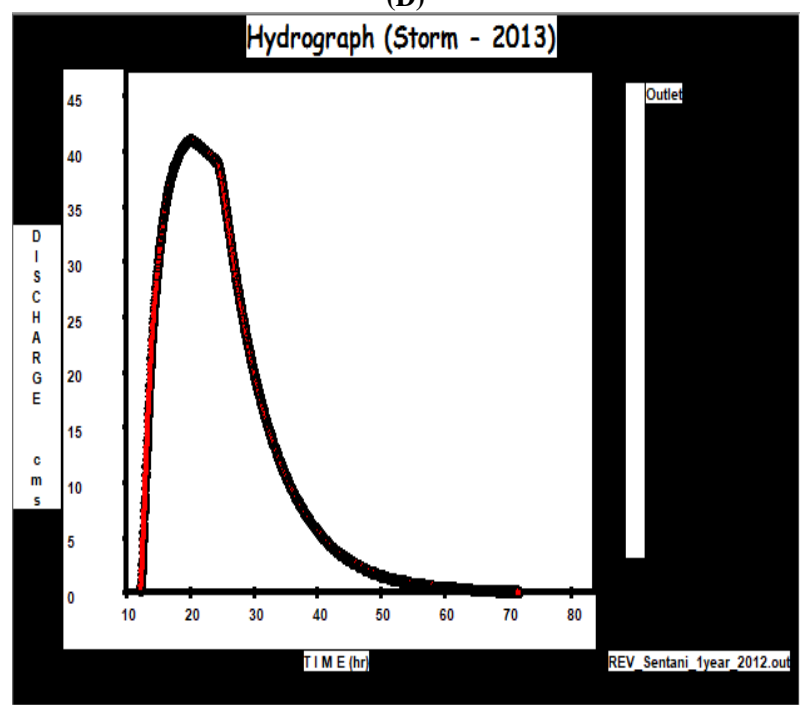

Fig. 7: Hydrograph Produced from Each Year Simulations; Results Are Shown in the Outlet. (A) Is the Simulation Result for 2007 Land Cover Composition, (B) is for 2010 Land Cover Composition, (C) is for 2012 Land Cover Composition, and (D) is for 2016 Land Cover Composition.

As it can be seen from above figures, the differences in between those years are not as distinct that it can be determined with naked eye. According to the calculation, from 2007 to 2010 there is an increment of about $6.616 \%$ in terms of outlet discharge, and $8.724 \%$ increment from 2010 to 2012, just in the span of two years. As for year 2016, in the past four years, the discharge produced by the simulation shows a declining trend of about $4 \%$, in other words the discharge produced in 2016 is $3.098 \%$ lower than the one produced in 2012.

In terms of Sentani's capability to reduce flood, it will also be discussed here. In year 2007, the capability is at $63.21 \%$, it means that Sentani lake acting as a reservoir can reduce up to $63.21 \%$ of the surface runoff flowing into the system. In year 2010, the capability is raised by about two percent, which is about $65.60 \%$ of total surface runoff. In 2010, the result raises even higher, that is $68.18 \%$, and for the last scenario of year 2016, the effectivity is reaching $69.71 \%$.

\section{Conclusion}

This paper revolves around the land use change issue and how it affects the hydrological response in an area. It also discusses about the retention capacity of Sentani lake acting as reservoir in terms of flood discharge reduction. The simulation is done over the years, taking year 2007, 2010, 2012, and recent 2016 as samples. The differences in between those years are not as distinct that it can be determined with naked eye. According to the calculation, from 2007 to 2010 there is an increment of about $6.616 \%$ in terms of outlet discharge, and $8.724 \%$ increment from 2010 to 2012, just in the span of two years. As for the year 2016, the discharge produced by the simulation shows a declining trend of about $4 \%$.

\section{References}

[1] River Flooding and Management Issues. (n.d.). Retrieved from GSCE Bitesize website: http://www.bbc.co.uk/schools/gcsebitesize/geography/water_rivers/river_flooding_management_rev1.shtml.

[2] Levi, C. (2013, Maret 27). Permukaan Danau Sentani Meluap Dua Meter. Retrieved from Tempo: https://pemilu.tempo.co/read/news/2013/03/27/058469748/Permukaan-DanauSentani-Meluap-Dua-Meter.

[3] Pattiselanno, F., \& Arobaya, A. Y. (2013). Danau Sentani: Kondisi Saat Ini dan Tantangan Pengembangannya di Waktu Mendatang. Bogor: Warta Konservasi Lahan Basah Vol. 21 No. 4. 
[4] Yusup Bungkang, S. D. (2014). Sentani Watershed Erosion Potential Study and Suspended Solid Distribution (TSS) In Connection with Lake Silting. IOSR Journal of Environmental Science, Toxicology and Food Technology (IOSR-JESTFT), 36-43.

[5] Arnold, C. a. (1996). Impervious surface coverage: the emergence of a key environmental. Journal of the American Planning Association, 243-258.

[6] Naulin, J. P. (2013). Spatially distributed flood forecasting in flash flood prone areas: Application to road network supervision in Southern France. Journal of Hydrology, 88-99.

[7] Soulis. (2011). SCS-CN parameter determination using rainfall-runoff data in heterogeneous watersheds - the two-CN system approach. Hydrological and Earth System Sciences, 1001-1015.

[8] USDA. (2015, February). WinTR-20: Project Formulation Hydrology. WinTR-20 Manual. United States Department of Agriculture. 